International Journal of Social Sciences and Humanities
Available online at http://sciencescholar.us/journal/index.php/ijssh
Vol.1 No. 3, December 2017, pages: 49 58
e-ISSN: 2550-7001, p-ISSN: 2550-701X
http://dx.doi.org/10.21744/ijssh.v1i3.55

\title{
Improving Cooperative Performance through Human Resource Development Efforts
}

\author{
CrossMark \\ Ida Ayu Oka Martinia; Ni Wayan Lasmi ${ }^{\mathrm{b}}$; NK Jayac; Ni Ketut Elly Sutrisni ${ }^{\mathrm{d}}$ \\ Article history: Received 25 July 2017; Accepted in revised form 7 November 2017; Approved 27 November 2017; \\ Available online 7 December 2017
}

Correspondence Author

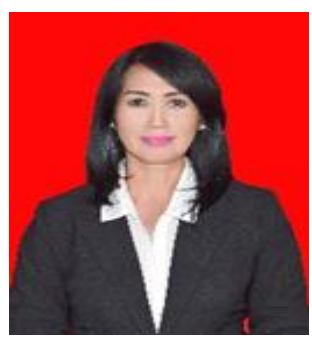

\section{Keywords}

Bali province;

Cooperative

management;

Cooperative;

Human resources;

Performance;

\section{Abstract}

Improving cooperative performance as one of the national and regional reconstruction teachers should be continuously carried out unlike the steps and anticipation by the many cooperatives that are bankrupt or disabled. The one aspect that needs to be improved was the aspect of Human Resources (HR) becomes manager and management of existing cooperatives. In order to realize it, the Department of Cooperatives and UMKM Bali Province has implemented various programs to improve the performance of cooperatives human resources that have been registered. The present research was conducted to measure the success level of human resource development from cooperative and relate to the cooperative performance that collected by Department of Cooperatives and UMKM during in 2016 period. The result of the document study was obtained concluded that have been done competency certification program for the manager and cooperative management, program education and training was attended by 1200 managers and cooperative management in Bali Province during in 2012 until 2016 period. Based on the programs that have been done, the Department of Cooperatives and UMKM Bali Province recorded a working realization of $218.89 \%$ or has exceeded the target set.

e-ISSN : 2550-7001, p-ISSN : 2550-701X@ Copyright 2017. The Author. SS Journals Published by Universidad Técnica de Manabí. This is an open-access article under the CC BY-SA 4.0 license (https://creativecommons.org/licenses/by-sa/4.0/) All rights reserved.

\section{Contents}

a Undiknas University, Denpasar, Bali-Indonesia

b Undiknas University, Denpasar, Bali-Indonesia

c Undiknas University, Denpasar, Bali-Indonesia

d Undiknas University, Denpasar, Bali-Indonesia 


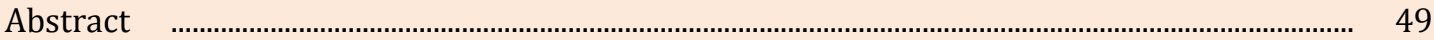

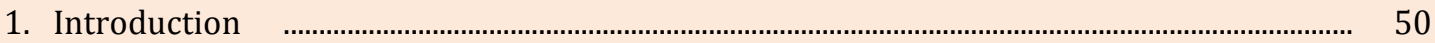

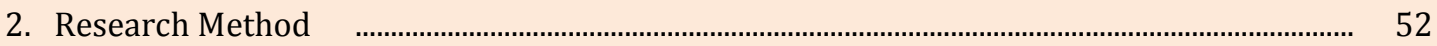

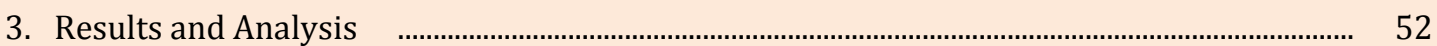

Cooperative of Human Resource Development by the Department of Cooperative and UMKM in Bali Province................................................................................................................. 52

Performance of Cooperative in Bali Province ................................................................................... 53

Human Resource Development Impacts on Achievement of Cooperative

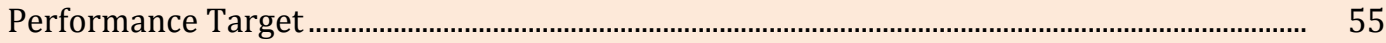

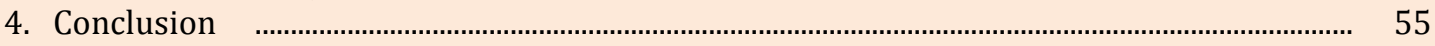

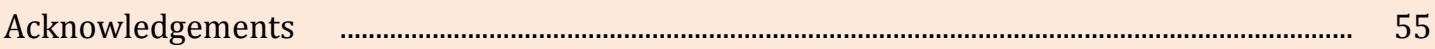

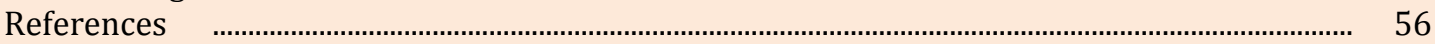

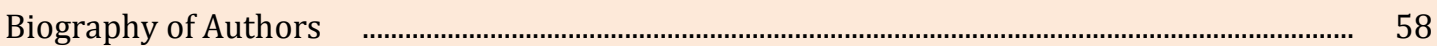

\section{Introduction}

The cooperative acts unlike driving force for the people's economy, due to it is mastering of the national economy. The cooperative role is very important in the economic life of the Indonesian nation, wherein, its existence is guaranteed by the law. Regarding one of the economic actors, the cooperatives play a role in economic development in a region. The development of cooperatives can be seen from its cooperatives existence that are beneficial to economic development. The cooperative is a forum for the development of economic democracy is also a vehicle to collect the potential of the scattered development among the citizens for the weak economic class. Based on the cooperative, the people will be able to improve their welfare by maximizing their participation and achievement in development according to their respective potentials based on the solidarity principle.

The development of cooperatives is not seen from the many cooperatives, but how healthy or not its cooperative units. A good or well cooperatives can be seen in terms of its cooperatives quality. In order to make a healthy and good, the key is all human resources (HR) cooperatives including managers must work hard, honest, and transparent to the members. ${ }^{1}$ The department of the cooperative and UMKM Bali Province revealed human resources in the field of cooperatives, in Bali is one of the problems being faced and it takes hard work to handle it. ${ }^{2,3}$

Regarding the existence of the reliable human resources, automatically will be able to improve the competitiveness of the local products to abroad and is expected to take advantage of opportunities to market the products not only penetrate of the domestic market but also reach the ASEAN market. ${ }^{4}$ This is evident from the data of Cooperatives and UMKM, Bali Province stated that there are currently about 4,934 cooperatives spread across regencies/cities in Bali. However, on the number, there are 529 inactive cooperatives. The number of cooperatives in 529 dormitory, 181 located in Gianyar regency, then 104 cooperatives in Badung, followed by 79 cooperatives in Denpasar, 46 cooperatives in Tabanan, 29 cooperatives in Bangli, 27 cooperatives in Karangasem, 21 cooperatives in Klungkung, 16 cooperatives in Buleleng, 16 cooperatives in Jembrana, and 10 cooperatives at the provincial level. It is currently noted, the Department of Cooperative, Bali Province dissolved 217 cooperative efforts in Denpasar area after previously in 2016, recorded 300 cooperative business which is out of business. Thus, the number of cooperatives that closed until it was dismissed as many as 517 cooperative efforts in nine districts and cities in Bali. This condition indicates that co-operative development has not been run optimally, therefore, many cooperatives folded or even dissolved. The coaching is very important to conduct, therefore, unlike not to affect other cooperatives that are still operating. ${ }^{5}$

In order to improve the performance of the cooperative, it is necessary to develop the human resources. The humans are the most important development resources among other resources that must constantly build capacity and power as implementers and drivers of development. ${ }^{6}$ Therefore, the development of the human resources must always be implemented due to the knowledge and technology is growing rapidly. Facing the ASEAN Economic Community (MEA), 
the Department of Cooperatives and UMKM must work hard in coaching human resources cooperatives, therefore unlike to compete with the ASEAN countries in terms of management and their own personal capabilities. ${ }^{2,3}$

In the framework, the department of cooperative and UMKM implement cooperative human resources development by on the job and off the job methods. The on the job method is a human resource development method implemented directly in the workplace. The on the job method implemented by the department of cooperative and UMKM is through competency certification program. Whereas, off the job method is a method of the human resource development that is implemented outside the workplace. Off the job method undertaken by the department of cooperative and UMKM is to include cooperative managers through education, training, and certification of competence. Based on the above description, the author will examine on 1) how human resources development implemented by the Department of Cooperatives, Small, and Medium Enterprises of the cooperative unit in Bali Province; 2) what is the performance achievement of cooperative in Bali Province.

\section{Literature review \\ Human Resource Management}

The human resource management is the science and art that governs relationships and the role of manpower in order to be effective and efficient in helping realize the goals of the company, employees, and society. ${ }^{7}$ The functions of human resource management include planning, organizing, directing, controlling, procurement, development, compensation, integration, maintenance, discipline, and dismissal. ${ }^{7}$ The purpose of human resource management includes the goals of society, organization, function, and personal.8,9 The purpose of society is to be socially responsible in terms of their needs and challenges arising from society, the organization's objective is to see the human resource management exists, it is necessary to contribute to the overall use of the organization, the purpose of function, is to maintain the contribution of other parts therefore they (human resources in each part) perform their duties optimally, then personal goals, is to assist employees in achieving their personal goals, to achieve organizational goals. The personal goals for their employee are expected to be fulfilled and become the motivation of the employee concerned.

\section{Human Resource Development}

The development is an attempt to improve the technical, theoretical, conceptual, and moral skills of employees in accordance with the work/occupation needs through education and training.7 Some of the human resource development methods used in the present research are education, training, and competency certification. The method of developing human resources into 2 methods, namely on the job method and off the job method.8, 9

1. Metode On the Job

On the job, a method is conducted through the competency certification. It is a process of providing of the competency certificates that are systematically and objectively carried out through competency tests that refer to the work competency standards both national and international. ${ }^{10}$ The competence measurement is based on the attitude, knowledge, skills, and expertise possessed by the certain person. The competency test is intended as a tool to obtain authentic valid evidence as a reference to whether the competency test participants have been competent or not of the competence material that has been tested. $^{24}$

2. Metode Off the Job

This method is divided into two namely education and training. The meaning of education and training is the process of transforming the quality of the human resources of the state apparatus that touches the four main dimensions of spiritual, intellectual, mental and physical dimension that are directed to the quality changes of the four dimensions of the human resources of the state apparatus. ${ }^{8,9}$

Martini, I., Lasmi, N., Jaya, N., \& Sutrisni, N. (2017). Improving Cooperative Performance through Human Resource Development Efforts. International Journal Of Social Sciences And Humanities (IJSSH), 1(3), 49-58. doi:10.21744/ijssh.v1i3.55 


\section{Cooperative Performance}

The Republic of Indonesia Law No. 25 in 1992, Article 1, Section 1 stated that a cooperative is a business entity consisting of a person or a legal entity cooperative with the basis of its activities based on the principle of cooperatives as well as a people's economic movement based on the principle of kinship. The Republic of Indonesia Law No. 25 in 1992, Article 3 then, the cooperative aims to promote the welfare of the members, in particular, the society in general and also to build the national economic order in order to realize a developed, just and prosperous society based on Pancasila and 1945 Constitution. The cooperative management should be conducted as well as possible in order to become a cooperative able to compete with other business entities, thus, the purpose of cooperatives can be achieved.

Measuring of the performance of a business entity, like cooperatives is very important, due to with the performance measurement of cooperative managers are able to know the effectiveness and efficiency of revenue cost, asset use, an operational process of the cooperatives management organization. Measuring of the cooperative performance is able to help decision-making about the educational needs of the human resource (HR) training, planning, and control in the process of the further cooperative management. The existence of performance measurement is expected to improve the cooperative effort thus, the welfare of members in particular and the society, in general, can be achieved. ${ }^{11}$

\section{Research Method}

The present research is a qualitative research, the data source used is secondary data obtained from the performance report of the Department of Cooperatives and UMKM in 2016 and online media. The techniques of collecting research data are by way of documentation related problems that will be discussed in the study. The data analysis using interactive model included data reduction, data presentation, and conclusion. ${ }^{30}$

The object of the research is the cooperative unit in Bali province. The research focus then is the development of human resources in the cooperative unit in Bali Province includes on the job method of the competency certification and off the job methods of training and education. The second focus is the performance of the cooperative in Bali province seen from the achievement of targets and target realization by the Department of Cooperatives and UMKM, Bali Province which consists of 1) increasing of cooperatives who excel; 2) increasing the growth of cooperatives and UMKM; 3) increasing financing facilities for cooperatives and UMKM; and 4) increasing the product marketing and partnership of cooperatives and UMKM. ${ }^{4}$

\section{Results and Analysis}

\subsection{Cooperative of Human Resource Development by the Department of Cooperative and UMKM in Bali Province}

The method at developing the cooperative human resources, the Department of Cooperatives and UMKM Bali Province take several steps, namely through competence certification, education and training.

a. Competency Certification

The Department of Cooperative and UMKMP Bali Provinsi improve the quality of Human Resources (HR) in the field of cooperatives through certification, especially at the manager level. Currently, about 30\% manager level 4,934 cooperatives registered in the Department of Cooperatives and UMKM in Bali Province that already has a competency certificate in 2010, therefore, there are still many level manager of a cooperative that has not been certified. Due to the Department of Cooperatives and UMKM provide workshop and socialization to cooperatives whose managers do not have certification. This certification aims to improve the professionalism of Savings and Loans Cooperative (KSP) in running their business due to it involves the management of money, especially those sourced from members of the cooperative for professional management. The success of a cooperative institution is largely determined by the quality of the people who manage. Thus, the role of human resources in cooperative institutions is not merely administrative however, it is more directed to how to 
develop it, to be creative and innovative. Along with the increasingly sharp competition due to rapid technological and environmental changes, the cooperative institutions require human resources that have the competence in order to provide excellent service and value. Thus, this certification is not only followed by managers but also treasurer, cashier and bottom..$^{25}$ it is recorded from the media of the Department of Cooperatives and UMKM have held competence certification for managers on 1-9 June 2012.15 Furthermore, the similar activities are conducted in 2017 on May in Badung, followed by 60 managers and cooperative bookkeepers in Badung. ${ }^{29}$

b. Education and Training

The education and training is one important element that must be implemented to increase of the knowledge and skills as well as insights in cooperatives. It should be carried out continuously, as a basis for sustaining the cooperatives survival. In accordance with the increasingly strategic role of cooperatives in building the populist economy, then, what needs to be strengthened is how to build a cooperative financial system, in order to improve the existing financial system and has been implemented. The cooperative financial system is one of the subsystems in cooperative development generally, so that the cooperatives can be a pillar in the national economy and encourage cooperatives parallel to other business entities. It is ensure, in order to build a healthy and accountable cooperative financial system, cooperative financial managers must understand the administration of the financial management including the accounting basics. In this regard, UPT. Training of Cooperatives and UMKM in Bali Province held training competency Head of KSP/USP Loan Bali Province Force I. Respecting the participants amounted 30 people from 9 regencies/cities in Bali. The competence training for KSP/USP Bali Level I loan is aimed to increase and improve the knowledge, skills and attitude changes needed by the cooperative managers to support operational technical tasks in the cooperatives financial management. ${ }^{20,21}$

It is not only the head section of KSP/USP Loan, but also the cooperative managers training in other regencies/cities in Bali, one of them is Denpasar. An implementation of training in Denpasar region focuses on the field of information technology. The mastery of the technology aims to cooperatives can take advantage of the development of IT for the cooperatives advancement. The training involves competent universities in the field of information technology as well as develops an entrepreneurial materials. It is not only in Denpasar, the training is also implemented in other regencies/cities, therefore, there later on will be more open cooperatives insight. ${ }^{33}$ Approximately 1,200 cooperative managers who have attended training in the human resources sector organized.20, 21 The training was conducted to address the main obstacles in developing cooperatives is from the aspect of the human resources (HR), to the capital and market sectors. In addition, the training is also in accordance with the efforts to grow a new entrepreneur. The provision of skill capital through, it is expected that cooperatives can compete in the middle of society to open the new businesses and opportunities.

\subsection{Performance of Cooperative in Bali Province}

In accordance with the vision of the Department of Cooperatives and UMKM Bali Province "The realization of Cooperatives, Micro, Small, and Medium Enterprises acts as the main actors in the regional economy to Bali Mandara" the contribution of cooperatives in Bali should be able to increase of the economic growth in Bali. Therefore, the performance of existing cooperatives in Bali must be well and continuously evaluated to sustain the economy in Bali province. Based on the performance report of the Department of Cooperative and UMKM in Bali Province, it is mentioned that the target set in assessing the cooperative performance consists of 4 points, included 1) increasing the cooperative who excel; 2) increasing the growth of cooperatives and UMKM; 3) increasing financing facilities for cooperatives and UMKM; and 4) increasing product marketing and partnership of cooperatives as well as UMKM.

Martini, I., Lasmi, N., Jaya, N., \& Sutrisni, N. (2017). Improving Cooperative Performance through Human Resource Development Efforts. International Journal Of Social Sciences And Humanities (IJSSH), 1(3), 49-58. doi:10.21744/ijssh.v1i3.55 
The result of data collection is then performed performance categorization (positioning) in accordance with the level of performance achievement with the results obtained as follows. The achievement of the first target of "increasing the cooperative achievement" consisting 2 indicators concluded that in the first indicator with a target 45 cooperatives that achievement can be realized a number 48 cooperatives which is a cooperative achievement or performance achievement $106.67 \%$. Last, the second indicator of the target 350 human resources competent cooperative managers can be realized a number 500 human resources cooperative managers who are competent or achieved second indicator performance $142.86 \%$. From these achievements, it can be stated in general the condition of cooperatives in Bali already has a strong institutional and increased business. The condition is as successful in conducting optimal training. In addition, it can be stated also that in general KSP/USP cooperative which assessed his health showed a very good condition.

The achievement of the second goal "increasing the growth of cooperatives and UMKM" consists of 2 assessment indicators. The first indicator related to the cooperative problem mentioned that from the target of cooperative growth amount, there is 300 cooperatives can be realized, 341 cooperatives in 2016 or achieved performance achievement $113.67 \%$. whereas, the second indicator for UMKM growth is $113.33 \%$. The achievement shows a good performance due to it has reached $68.20 \%$ of the year-end target of the Strategic Plan set. The achievement of performance indicators is supported by the implementation of Cooperative Institutional Quality Improvement Program on Development Activity Information System of Cooperative Development Planning.

The achievement of the third goal "increasing of financing and guarantee facilitation for cooperatives and UMKM" as well as consists 2 indicators. The first indicator related to the field of cooperatives mentioned that from the target $3.5 \%$ cooperatives that get financing can realize about $9.43 \%$ cooperatives that have obtained financing facilities. Based on these values, there has been a performance achievement in 2016 about $269.43 \%$. The second indicator of financing facilities for UMKM achieved achievement of $562.48 \%$. The achievement of both indicators shows good performance because it has exceeded the specified target. Meanwhile, when compared with the year-end target Renstra (Strategic Plan) has reached 235.75\%. The supporting factors of the achievement of the indicator are caused by the cooperative access to the credit scheme in the bank has started to increase. The capital strengthening fund owned by Bali Provincial Government has begun to be utilized by the Cooperative as a source of capital and the existence of credit guarantee institution for Bali Mandara (Jamkrida) to guarantee credit proposed by the Cooperative. Supporting the achievement of the performance indicators through the implementation of Business Support System Program for Micro, Small, Medium Enterprises (UMKM) on Facilitation/ socialization Activities of Information Support of Capital Supply/Financing and Infrastructure for Cooperatives.

An achievement of the last fourth goal is "increasing of marketing of the cooperative products and UMKM" consists of 1 assessment indicator that is a number of cooperative and UMKM that partner and its product is known to the public. Based on the target set about 42 cooperatives and partnered UMKM can be realized about 94 cooperatives that do a partnership with the local governments or private institutions. The resulting performance value, indicating the performance achievement of indicators in 2016 amounted $223.81 \%$. the performance achievements far exceeded the set targets. When it compared with the year-end target of Renstra in the Performance Report of the Department of Cooperatives and UMKM Bali Province 2016 has reached $134.28 \%$. the factors affecting the success of achieving, these performance indicators are supported from various sectors, both from the Government, business, banking, and SOEs to become KUMKM partners in terms of capital and marketing through Partnership Meeting and promotion of KUMKM products. The Government is also conducting unlike activities to establish cooperation between KUMKM and the business world, banking and SOE through the implementation of Entrepreneurship Development Program and Competitive Advantage of Small and Medium Enterprises in Facilitation Activities of Network Development/Business 
Partnership and Promotion of Cooperative Product and Cooperative Facilitating Business Enhancement Partnership.

The results of achievement for 4 goals that have been determined on average known $218.89 \%$ and fully supported by the budget of the Bali Province Budget in 2016. In general, from the budget given IDR. 7,043,245,263 happened budget absorption (realisation) is IDR. 6.493 .480 .421 or equal to $92.19 \%$ of the initial budget. It is ensured if this is linked to the achievement of objectives with the budget absorption, achievement of a very good goal $218.89 \%$ will be followed by the absorption $92.19 \%$. Based on the data on the achievement of the targets and the absorption of the budget indicates that the funds provided for the achievement in 2016 target are sufficient.

\subsection{Human Resource Development Impacts on Achievement of Cooperative Performance Target}

The successful achievement of the performance targets cooperatives in Bali province in 2016 can not be separated from the programs that have been planned by the Department of Cooperatives and UMKM Bali Province in a structured. These programs are also an effort of the department to further discipline, fostering registered cooperative managers, therefore, the cooperative's performance output is better. The human resource development programs unlike the competency education and training for managers and employees of the cooperative have been able to increase the competence of the board to manage the cooperative like a way that the welfare of the members and more importantly improve the cooperative performance as a whole.

The achievements of the cooperative human resources development program have been fully seen to improve the performance of the cooperative in Bali Province. The linkage between the human resource development programs that can improve cooperative performance is supported by some previous researchers. ${ }^{13}$ The research results that training and human resources development have an effect on increasing employee motivation and commitment so that in the end can increase the organization productivity too. Other research results conclude that the aspects of the human resource development have a positive and significant influence on organizational performance. ${ }^{35}$ Whereas, the aspects of human employee performance greatly affect the performance of a company or business entity. ${ }^{27}$ An Individual performance in a company or business entity has a very important influence on the quality of the implementation of the management functions as well as overall operations, both for short or long term.

\section{Conclusion}

The human resource development has been conducted by the Department of Cooperatives and UMKM Bali Province by conducting Education and Training of competency certification on cooperative management ranging from the level of manager to employees. This program has been implemented since 2012 until present. It is recorded approximately 1200 cooperative managers who have followed the Training that is implemented. The impact of cooperative management competencies in Bali Province is related to the performance of cooperatives having a one-way relationship. Based on data of achievement of the target performance achievement is reflected in the achievement of the main performance indicator determined by various factors, included the human resources, budget, and infrastructure. The results of Performance Report of Cooperatives and UMKM in 2016 stated that the existing performance indicators have exceeded the target set or realized performance achievement $218.89 \%$.

\section{Acknowledgements}

The authors thank the Rector of National Education University, Denpasar, the Dean of the Economics and Business, National Education University, and our friends who have supported and the Department of Cooperatives and UMKM Bali Province who has assisted in providing information and the research data, therefore, the present article is completed on time. God bless you.

Martini, I., Lasmi, N., Jaya, N., \& Sutrisni, N. (2017). Improving Cooperative Performance through Human Resource Development Efforts. International Journal Of Social Sciences And Humanities (IJSSH), 1(3), 49-58. doi:10.21744/ijssh.v1i3.55 


\section{References}

1. Baliekbis.Koperasi Sehat Kuncinya Kerja Keras dan Jujur. Diakses Agustus 09, 2017. View in (Google)

2. Kartikaningrum, N. I. (2015). Bali tingkatkan kualitas SDM koperasi. View in (Google)

3. Kartikaningrum, N. I. (2015). Hadapi MEA, Dinkop UKM Bali fokus masalah SDM. View in (Google)

4. Warta Ekonomi. Diskop Bali: SDM Kunci Keberhasilan UMKM Hadapi MEA. View in (Google)

5. Indonesiakoran.Dinas Koperasi Bubarkan 517 Koperasi di Bali. Diakses Agustus 10, 2017. View in (Google)

6. Kartasasmita, G. (1996). Pembangunan untuk rakyat: memadukan pertumbuhan dan pemerataan. Cides. View in (Google Scholar) (Scopus)

7. Hasibuan, M. S. (1990). Manajemen sumber daya manusia: dasar dan kunci keberhasilan. Haji Masagung. View in (Google Scholar) (Scopus)

8. Sedarmayanti, M., \& Pd, M. (2001). Sumber daya manusia dan produktivitas kerja. Bandung: Mandar maju. View in (Google Scholar)

9. Sedarmayanti, M. P. (2001). Sumberdaya Manusia dan Produktivitas Kerja Karyawan. Bandung, Refika Aditama. View in (Google Scholar)

10. BNSP. (2017). View in (Google)

11. Ikhsan, S. (2005). Pengukuran Kinerja Koperasi. View in (Google Scholar)

12. Adetunji, A. T., Adetunji, A. V., Adeleke, E. O., \& Madubuike, S. C. (2017). Deregulation: The Effect of Market-led Approach to Nigerian Universities Management. International Journal of Social Sciences and Humanities (IJSSH), 1(1), 1-8. View in (Google Scholar)

13. Agwu, M. O., \& Ogiriki, T. (2014). Human Resource Development and Organizational Performance in the Nigeria Liquefied Natural Gas Company Limited, Bonny. Journal of Management and Sustainability, 4(4), 134. View in (Google Scholar)

14. Amerta, I. M. S. (2017). The Role of Tourism Stakeholders at Jasri Tourism Village Development, Karangasem Regency. International Journal of Social Sciences and Humanities (IJSSH), 1(2), 20-28. View in (Google Scholar)

15. Ayu. (2012). Manajer Se-Bali Ikuti Sertifikasi Kompetensi. View in (Google)

16. Basak, A., \& Khanna, K. (2017). A Study on the Selection Criteria of Different Hotels of Delhi NCR in Accordance to the HR Policies and Market Trends. International Journal of Social Sciences and Humanities (IJSSH), 1(1), 27-38. View in (Google Scholar)

17. Billaiya, R., Malaiya, S., \& Parihar, K. S. (2017). Impact of Socio Economic Trends on Students in Quality Education System. International Journal of Social Sciences and Humanities (IJSSH), 1(1), 16-20. View in (Google Scholar)

18. Cedeño, M. L. D., Arteaga, M. G. D., Pérez, A. V., \& Arteaga, M. L. D. (2017). Regulatory Framework for Renewable Energy Sources in Ecuador Case Study Province of Manabí. International Journal of Social Sciences and Humanities (IJSSH), 1(2), 29-42. View in (Google Scholar)

19. Denpost. Ratusan Koperasi di Bali Mati Suri. View in (Google Scholar)

20. Dinkop dan UMKM. (2016). Laporan Kinerja (LKjLP) Dinas Koperasi, Usaha Mikro, Kecil dan Menengah Tahun 2016. View in (Google Scholar) (Scopus)

21. Dinkop UKM Bali. (2017, Juli 18). View in (Google Scholar)

22. Gámez, M. R., Pérez, A. V., Será, A. S., \& Ronquillo, Z. M. (2017). Renewable Energy Sources and Local Development. International Journal of Social Sciences and Humanities (IJSSH), $1(2), 10-19$. View in (Google Scholar)

23. Ghosh, C. (2017). A Study on-Evaluating Marketing Strategies Adopted by Home Appliance for Economic Development in India. International Journal of Social Sciences and Humanities (IJSSH), 1(1), 9-15. View in (Google Scholar)

24. Ilmu MSDM. (2017). Peranan Kompetensi Manajemen SDM Dalam Dunia Kerja. View in (Google Scholar)

25. Ivooxid. Bali Genjot Kualitas SDM Koperasi Melalui Sertifikasi. View in (Google Scholar) 
26. Jain, P. (2017). Cashless System of Colleges in India. International Journal of Social Sciences and Humanities (IJSSH), 1(3), 1-7. View in (Google Scholar)

27. Karmilawati, N. I. (2009). Keterikatan Karyawan sebagai Mediasi Budaya Organisasi dan Efektivitas Manajemen Sumber Daya Manusia pada Kinerja Karyawan: Studi Empirik di BUMN - Industri Pertambangan Mineral Indonesia. Dissertation. Program Doktor Ilmu Ekonomi Kekhususan Manajemen Bisnis. Bandung: Unpad. View in (Google Scholar)

28. Larantika, A. A. A. D., Zauhar, S., Makmur, M., \& Setyowati, E. (2017). Collaboration as a Strategy for Poverty Alleviation. International Journal of Social Sciences and Humanities (IJSSH), 1(3), 40-48. View in (Google Scholar)

29. Metro Bali. Wujudkan Koperasi Sehat Dan Hebat Badung Gelar Diklat dan Uji Sertifikasi Kompetensi Manajer dan Juru Buku Koperasi. Diakses Agustus 08, 2017. View in (Google Scholar)

30. Miles, B. (1992). Matthew dan Huberman, A. Michael,"Analisis Data Kualitatif Terjemahan Tjetjep Rohendi Rohidi", Jakarta: Penerbit Universitas Indonesia. View in (Google Scholar)

31. Nahak, S. (2017). Criminal Law Policy on Land Functions Impacting Climate Change in Indonesian National Law Perspective. International Journal of Social Sciences and Humanities (IJSSH), 1(3), 28-39. View in (Google Scholar)

32. Indonesia, R. (1999). Undang-Undang No. 8 Tahun 1999 Tentang Perlindungan Konsumen (No. 42). Lembaran Negara RI Tahun. View in (Google Scholar)

33. Rhismawati, N. L. (2017). Dinkop Bali mantapkan keterampilan koperasi. View in (Google Scholar)

34. Suparsa, I. N., Mantra, I. B. N., \& Widiastuti, I. A. M. S. (2017). Developing Learning Methods of Indonesian as a Foreign Language. International Journal of Social Sciences and Humanities (IJSSH), 1(2), 51-57. View in (Google Scholar)

35. Susilowati, Y., Hutagaol, P., Pasaribu, B., \& Djohar, S. Pengaruh Aspek Pengelolaan Sumber Daya Manusia terhadap Peningkatan Kinerja Organisasi di Industri Otomotif di Indonesia. View in (Google Scholar)

Martini, I., Lasmi, N., Jaya, N., \& Sutrisni, N. (2017). Improving Cooperative Performance through Human Resource Development Efforts. International Journal Of Social Sciences And Humanities (IJSSH), 1(3), 49-58. doi:10.21744/ijssh.v1i3.55 


\section{Biography of Authors}

\begin{tabular}{|c|c|}
\hline & $\begin{array}{l}\text { Ida Ayu Oka Martini, SE., MM. was born on March } 25^{\text {th }}, 1966 \text {. She lives } \\
\text { at Jalan Tunggul Ametung VI No. } 12 \text { Denpasar. She is a senior lecturer } \\
\text { at Undiknas University, Denpasar, Indonesia and a civil servant. She } \\
\text { had finished her Bachelor Degree at Warmadewa University in } 1990 \\
\text { and she completed her Master Degree at Krisna Dwipayana University, } \\
\text { Jakarta. She currently is Ph.D. student at Udayana University. She is } \\
\text { interested in Management Science. }\end{array}$ \\
\hline & $\begin{array}{l}\text { Ni Wayan Lasmi, SE., MM. was born on August } 29^{\text {th }}, 1961 \text {. She lives at } \\
\text { Jalan Kerta Dalem Sari II/6 Denpasar. She is a senior lecturer at } \\
\text { Undiknas University, Denpasar, Indonesia and a civil servant. She had } \\
\text { finished her Bachelor Degree at STIK Denpasar in } 1986 \text { and she } \\
\text { completed her Master Degree at STIM Jakarta in 1998. She is } \\
\text { interested in Management of Economics and Financial. }\end{array}$ \\
\hline & $\begin{array}{l}\text { Drs. N K Jaya, MM. was born on January } 13^{\text {th }}, 1955 \text {. He lives at Jalan } \\
\text { Tukad Languan No.25 Denpasar. He is a senior lecturer at Undiknas } \\
\text { University, Denpasar, Indonesia and a civil servant. He had finished } \\
\text { her Bachelor Degree at STIK Denpasar in } 1986 \text { and he completed her } \\
\text { Master Degree at STIM Jakarta in 1998. She is interested in } \\
\text { Management of Economics and Financial. }\end{array}$ \\
\hline & $\begin{array}{l}\text { Ni Ketut Elly Sutrisni, SH., MM. was born on February } 22^{\text {nd }}, 1962 \text {. She } \\
\text { lives at Jalan Dewata III No. } 2 \text { Sidakarya Denpasar. She is a senior } \\
\text { lecturer at Undiknas University, Denpasar, Indonesia and a civil } \\
\text { servant. She had finished her Bachelor Degree in Legal Science in } 1985 \\
\text { and she completed her Master Degree in Management in 1996. She is } \\
\text { interested in Management an Legal Science. }\end{array}$ \\
\hline
\end{tabular}

